УДК: 821.163.41.09 Караџић В. С. DOI: https://doi.org/10.18485/belic_slv.2018.3.ch20

\title{
Бошко Сувајџић
}

\section{ИВО АНДРИЋ О ВУКУ КАО ПИСЦУ}

Андрић је, као што се зна, девет својих студија, есеја, пригодних осврта и чланака посветио Вуку Караџићу. Први пут су његови списи о Вуку, поводом пишчевог 80. рођендана, обједињени у књизи коју су Вуков и Доситејев музеј и БИГЗ објавили под насловом Иво Андрић о Вуку Караиићу (рукопис припремио Ђуро Гавела, Београд, 1972). У књизи су се нашли чланци: „Вук реформатор” (1947); „О Вуку као писцу” (1946), „Вук и иностранство” (1947), „Вуков пример” (1947) и „Вуков оптимизам" (1964).

Свих девет есеја публиковао је у књизи под насловом Иво Андрић o Вуку један од најзаслужнијих проучавалаца Вукова дела, истакнути вуковац, Голуб Добрашиновић. Књигу отвара Андрићева приступна беседа, „О Вуку као писцу”, одржана 24. јануара 1946. на свечаном скупу Српске академије наука. Андрић је за академика изабран још 1939. године. Рад „О Вуку као писцу” представља несумњиво централни Андрићев есеј о Вуку, студиозно припреман и смишљено одабран. Ту су и још три Андрићева огледа о Вуку („Вуков пример”, „Вук и иностранство” и „Вук, реформатор", 1947), предавање одржано на свечаној академији на Коларчевом народном универзитету 7. фебруара 1964, поводом 100-годишњице Вукове смрти, објављено под насловом „Оптимизам Вука Караџића” (1964), дијалошки текст „Три слике из живота Вука Караџића” (1950), као и три необјављена списа из Андрићеве оставштине о Вуку: одломак, по свој прилици, неоствареног сценарија за филм о Вуку (1947), ${ }^{1}$ предавање

1 „Исте године њему се обратило Министарство просвете да напише сценариј о Вуку. Опирући се у почетку, - сећа се тадашњи министар просвете Митра Митровић, - најзад је пристао и прихватио се тога. Ревностан и трудољубив, посветио је пуно пажње и Вуковом делу и литератури о њему, али посао, судећи бар према сачуваном рукопису, није привео крају. На уводном листу забележио је: 'Није никад остварен овај сценарио. Ставити у досје: Вук”' (Добрашиновић 1977: 6). 
у Удружењу књижевника Србије о Вуковом односу према књижевном позиву, поводом прославе 100-годишњице победе народног језика, 1947. године, и један краћи напис о Вуку (в. Добрашиновић 1977: 6).

У Андрићевој, не много обимној есејистици Вук је, као што видимо, добио знатно места, а у обилатој литератури о Вуку његови списи делују самосвојно и свеже, с лепим мислима и опаскама и оштроумним закључцима. У њима велики уметник лепе речи више иде за чињеницама и чињеничним судовима, мање за надменим синтезама. Из њих избија студиозна обавештеност не само о Вуковом делу и његовој преписци већ и о важнијој литератури о Вуку (Добрашиновић 1977: 7).

Вредно је напоменути да је Андрић најважније есеје о Вуку, у којима доминира јединственост погледа на значај, духовни профил, револуционарну суштину и борбену хероику Вуковог живота, лика и дела, написао у првим послератним годинама (1946-1947). То јасно говори о томе да је велики писац вуковску традицију недвосмислено изабрао и декларативно обзнанио као своју. И не само због тога што смишљено бира тему „О Вуку као писцу” за своју приступну академску беседу, чиме наглашава оно што магистрално одређује његову поетику и књижевне утицаје, већ и због јединственог концепта којим Вука означава као свог директног књижевног претходника, па и по цену да одређене своје ставове понавља и варира у различитим есејима, што је Андрићу, као врсном стилисти, посве несвојствено. Чини се као да ови есеји представљају неку врсту послератног књижевног манифеста Иве Андрића, у коме велики писац, за нијансу прегласно, обзнањује припадност вуковској традицији, и посвећеност револуционарној природи те традиције и с муком извојеване победе.

Јединственост концепције, фокусираност и усредсређеност на лик и дело Вука Караџића, обично се тумаче Андрићевом опчињеношћу Вуковом херојском и визионарском борбом. Андрић Вуку као реформатору приступа увек тако да што снажније нагласи „револуционарни феномен” његове борбе. Вук је за Андрића „рушилац и градитељ, и више градитељ него рушилац, али је савременицима, нарочито у прво време, морала бити много више видљива рушилачка страна његовог потхвата”. Ипак, не треба заборавити да средишни Андрићев есеј о Вуку носи наслов „О Вуку као писцу”. И да Андрић овде рашчлањава Вуково дело изнутра, из његових најважнијих поетичких претпоставки:

U rasponu od preko godinu dana (1946-1947) objavio je Ivo Andrić glavninu svojih zapisa o Vuku Karadžiću i svi oni počivaju na istom, je- 
dinstvenom Andrićevom konceptu Vukove ljudske, duhovne i stvaralačke ličnosti. [...] Andrićeva vizija Vuka ostvarila se blagodareći tome što je sve spoljašnje kao mogućni kriterij i objašnjenje u tumačenju ostalo izvan nje. Andrić je gledao Vuka iznutra, iz njegova dela, potom iz duhovnosti njegove ličnosti ostvarene u delu. „Duhovna fizionomija i moralni lik”, Vukova srčanost i moralna čvrstina, upornost i vera, prirodna ali usavršavana svojstva, razotkrili su Andriću Vuka kao neimara koji gradi uvek iz početka, ako treba, ne obazirući se na noćne sile što obaraju obdan sagrađeno, ne mareći da iziđe „na onu stranu sav poderan i krvav”, „samo neka se zna staza kojom bi se drugi mogao lakše usuditi da prođe”. Vuk nije radio za sebe već „Za narod”, iza njega stajala je čestitost motiva a ispred njega čistota njegova cilja. Zato je i mogao, bez zazora, sam izmeriti svoj rad i svoje zasluge (Крњевић 1980: 151-152).

С друге стране, не треба заборавити ни то да су Андрићева дела о Вуку увек написана $c$ поводом. Од оног, најважнијег, приступне академске беседе, у којој се по природи ствари акценат ставља на основну област истраживања, преко обележавања важних јубилеја и годишњица. Андрићев став о Вуку, током свих ових година, остаје неизмењен:

Иво Андрић је о Вуку Караџићу дао неколико прилога, међу којима се издвајају приступна академска беседа „о Вуку као писцу” из 1946. године и годину дана касније написан оглед „Вук, реформатор". Те 1947. године, поводом стогодишњице онога што се обично назива Вуковом победом, Андрић је објавио и краће чланке „Вуков пример” и „Вук и иностранство”, у којима нема нових идеја, а неки делови су дословно преузети из огледа „О Вуку као писцу” и „Вук, реформатор”. Сличан је случај и са доста касније написаним огледом „Оптимизам Вука Караџића”, такође писаним са поводом да буде изговорен на скупу посвећеном стогодишњици Вукове смрти: безмало две деценије после претходних огледа, Андрић из њих преузима не само поједине реченице, већ и читаве пасусе, у закључку тек нешто мало другачије формулисавши место Вука Караџића у српској култури, али тако да ни то не одступа од основне линије начина на који га је „представљао” (Николић 2012: 367).

Питање Вукове борбе за језик Андрић је с разлогом, и с правом, увек везивао за књижевност. Оно што је Вук чинио увођењем новоштокавских херцеговачких говора у књижевност учинили су у италијанској књижевности Данте, у руској Пушкин, у немачкој Лутер, у пољској Мицкјевич и др. Вук није нормирао књижевни језик. Вук га је усмеравао у правцу у 
коме му је то „пришаптавала” књижевност. Књижевност првога реда и високе, непроцењиве вредности:

Jezik ide kud hoće, ali sluša šta će mu književnost prišapnuti. Bez Dantea ne bi bilo ujednačenog italijanskog jezika. Kada Dante u delu De vulgari eloquentia analizira i osuđuje razne italijanske dijalekte, postavljajući sebi za cilj da iskuje novi, pročišćeni narodni jezik, za takav čin oholosti niko ne bi stavio ruku u vatru, a ipak je svojom Komedijom postigao šta je hteo. Doduše, bilo je potrebno nekoliko vekova da bi danteovskim narodnim jezikom svi i progovorili, ali je on uspeo zato što je zajednica onih koji su u književnost verovali neprestano otuda crpla nadahnuće i obrasce. A da tog ugledanja nije bilo, ni zamisao o političkom ujedinjenju ne bi prokrčila sebi put. [...] Književnost, doprinoseći obrazovanju jezika, stvara identitet i zajedništvo. Prvo sam pomenuo Dantea, ali pomislimo samo šta bi bilo od grčke kulture bez Homera, od nemačkog identiteta bez Luterovog prevoda Biblije, od ruskog jezika bez Puškina, od indijske kulture bez spevova u njenom temelju" (Еко 2015: 8-10).

Не треба заборавити какве су књижевне и културне прилике Вука затекле у Србији. Па ни какве је он сам затекао међу ученим, варошким Србима у Аустрији. О томе, врло опоро и горко, сведоче уредници српске књижевне периодике, која је у повоју. Између осталих, Богобој Атанацковић у пропратној речи Книге за добре цели (Нови Сад, 1852, стр. 87), Јаков Игњатовић, као уредник Летописа Матице српске 1854-1856. године, или пак Ђорђе Поповић, уредник Седмище:

Током 18. и у првој половини 19. века у српској прози владали су преводни жанрови, басне, приче из класичне старине, библијске параболе, источњачке приповетке, идиле, прераде и посрбе свакакве врсте начињене према мање вредним и значајним страним ауторима, као и приче из живота (о врлинама) или новије историје, као и приповетке више окренуте сентиментализму и неговању морала код читалаца. Таква је била тада лектира првога реда. Примат су имале приче у знаку наравоученија, васпитавања јуности, али и грађанског сталежа у повоју који се у Срба тек привикавао на књигу и споро укључивао у читалачки круг (Матицки 2017: 20-21).

Андрић је високо вредновао активну, стваралачку, борбену димензију Вукове личности. Истицао је посебно „како је узвишени Гете, који ником није пружао руку, одступио од своје навике приликом сусрета с Балканцем Вуком". Вукову беспоштедну борбу против свију и свега што 
је у српској култури било моћно и утицајно, од школе до цркве, стаменост која му је омогућила да „одоли невиђеним искушењима, понижењима, увредама, клеветама, беди, болестима и многобројним родитељским несрећама" (Добрашиновић 1977: 7-8). Радо и често је наводио познате Вукове речи да ће „тумарнути кроз трње макар на ону страну сав подеран и крвав изашао", уз нескривено дивљење према човеку који зна да ће изаћи из трња, па макар крвав и подеран. Истицао како се Вук у личном животу, како наводи један његов биограф, „повијао и довијао, гутао срамоту, служио горег од себе, мољакао, али у основној ствари, у својој визији народног језика, остао је прав и непоколебљив, реформатор, борац и победник" (Добрашиновић 1977: 9-10).

И у изврсној књизи Меше Селимовића За и против Вука овој, „епској” димензији Вукове делатности, одаје се високо признање:

Вук, устаник који прима ударце и немилосрдно их задаје, који без жаљења оставља мртве за собом, једна концентрисана и систематизована стихија, идеолог и апологет победоносног српског сељаштва, најбројнијег и најдинамичнијег дела народа у то време, упустио се у борбу против једног на изглед кремено чврстог света, против угледних појединаца, против свих тадашњих књижевника, против моћних институција, против митрополита, против владара, против целог једног друштвеног система. Невероватна комбинација устаничког голаћа, сељачког трибуна, видовитог политичара и педантног научника, Вук је 'тумарнуо' у историјску гужву, у мутну матицу и, након четврт века непрекидне и свестране активности, пркосно огласио победу: „Хвала Богу! Ево нас већ на обали!” (Селимовић 1983: 39)

Ипак, суштинско Андрићево интересовање усмерено је према Вуку као писиу.

У нашој научној књижевности појава Вука Ст. Караџића, као „централне личности српске књижевности у средини XIX века”, проучавана је и испитивана са разних страна и у њеним многобројним односима. Али о Вуку као писцу, о духу, облику и техници његовог књижевног израза није много писано (Андрић 1977: 17).

Питања Вуковог књижевног образовања, литературе и узора, Андрић оставља по страни. Уосталом, о томе се у српској науци водила дуга и прилично јалова полемика (в. Сувајџић 2015: 125-147): 
Према суду историје књижевности, Вук је поникао и радио „у идејама сувременог романтизма", као што је и његов ментор Копитар „припадао романтичарском бечком кругу”. И формално је тачно да Вук има са романтичарима заједничку полазну тачку, тј. култ народних песама и старине. Али оно што га од самог почетка видно одваја и у чему се он битно разликује од истинских романтичара, то је чињеница да њега из прошлости занима редовно „жива старина”, тј. оно из прошлости што утиче на садашњост и условљава будућност народа. То је Скерлић уочио и, осетивши потребу да ближе одреди и ограничи Вуков тобожњи романтизам, он је рекао за Вука „романтичар по идејама, он има рационалистички дух” (Андрић 1977: 17).

Народна књижевност, митови и легенде, историја, обичаји, жива стварност, здрав разум и истина. То су Вукове лозинке. Или пак Андрићеве?

За цело његово дело могло би се казати оно што је он рекао још у почетку о својој борби за народни језик: „Ту господари здрави разум и истина...”

И то се у Вуковом делу и животу враћа као рефрен: „Оно су несрећни људи, који су ум свој дали под аренду, па сад морају да мисле како други оће”, пише он. „Ја бирам оно што ми показује $y м$, а не светцу за атар", писали су Вуку његови пријатељи као Павле Барић, кад су хтели да му буду блиски и по вољи. „Кога се бојите, кад вам ум каже да онако треба?” довикивао је Вук колебљивом и обазривом Лукијану Мушицком. [...]

У свом дугом и тешком животу Вук се повијао и прилагођавао у многим стварима („по слабости људској”), али је у једном остао непоколебљив, тј. никад није у свом књижевном делу „дао ум под аренду”, никад није дао „умље за безумље” (Андрић 1977: 18-19).

Оно што Андрић такође програмски истиче код Вука јесте нерашчлањивост Вукових приповедних светова и полемичких и критичких чланака, његов јединствен и непоновљив стил, ма у коме се жанру он конкретизовао:

Вукови су чланци, с обзиром на њихове књижевно-језичке и полемичке аспекте, готово нерашчлањиви. Однос према језику појављује се као супстанца свих критичких текстова, у непосредној вези с природом писане праксе по себи. [...] У критикама књижевних дјела, полемикама, 
дијелу предговора̂, водеће мјесто има језик у граматичким, лексичким, синтаксичким и стилским распонима. То су, међутим, оквири који обухватају идеологију и стратегију препорода цјелокупног подручја писане ријечи. Вукова мисао је отворена према дјеловању и при томе саопштена у врло разноликим облицима: непосредно, најчешће полемички, и посредно, помоћу пословице, афоризма, шаљивих причица, анегдота, парабола, примјера, стапајући ове облике са аргументима (закључцима и сл.). Та својства, расијана по свим овим текстовима, дају им јединствен ауторски печат и јединствен стил у српској писаној ријечи: дискурзивност се стапа с приповиједањем, а несуздржана полемичност са иронијом, пародијом, гротеском и сличним средствима подривања смисла туђе ријечи, слике или става (Иванић 2014: 23-24).

Ако би требало тражити шта чини основу Вуковог стила, то је оно што је сам Вук највише ценио код својих певача и казивача. Логика, смисао, прегледност, јасност у излагању. Он је, „за разлику од простих скупљача, умео да распознаје главно од спореднога, важно од неважнога”, како тврди Слободан Јовановић (1991: 659), уз приповедачки дар и „осећање унутрашњег јединства и код људи и код догађаја” (1991: 663):

Кад је писао о људима, које је имао прилике да изблиза посматра, Вук их је насликао тако живо да они, чак и нама који их нисмо познавали, изгледају „погођени”. То нису оне парадне слике које се праве за потомство: то су тренутни снимци, који су изненада ухватили свог модела у његовом најкарактеристичнијем ставу (Јовановић 1991: 662).

И управо је то живо, оштроумно, а истовремено високо миметичко приповедање и описивање савременика и догађаја Андрић издвојио као карактеристичну одлику књижевног поступка Вука Караџића:

Речено је: „Вук је творац чисте српске прозе и стила” (Љ. Стојановић). Гледајући боље и изближе Вукову прозу, могло би се слободно рећи: Рационалиста по својим схватањима и погледима, Вук је реалиста по поступцима и начинима на које оно што је видео и сазнао књижевно приказује и уобличава. [...] Међу особинама које тражи техника доброг писца реалисте, три су, по нашем схватању, битне. То су: пажња, избор и смисао за карактеристичну појединост (Андрић 1977: 22-23). 
Ненад Николић у Андрићевом писању о Вуку препознаје

стратешко успостављање Вука као апсолутног темеља изостављањем чињеница које је Андрић морао знати и пренебрегавањем изразито упадљивих противречности, јер све то упућује на потребу да се Вук монументализује старију од конкретног испитивања његовог дела. Та потреба нарочито долази до изражаја када се Андрићеви ставови о Вуку упореде са огледом „Вук као сликар историских личности" Слободана Јовановића из 1938. године и књигом За и против Вука Меше Селимовића из 1967. године (Николић 2012: 368).

Поставља се питање у којој мери се Андрићево приповедање може и сме самеравати Вуковим стилом, а језик вуковским „ауторским гласом”:

„Вук је у овом поступку исто толико индивидуалан колико је индивидуалан и сваки народни усмени приповедач - интерпретатор, али мање него приповедач стваралац", констатује Нада Милошевић Ђорђевић (2002: 108). Хтјели смо, међутим, рећи да је Вук индивидуалан у већем степену него прави усмени приповједачи, условљено укупном његовом списатељском дјелатношћу и циљевима које је поставио свом раду. У издањима народних приповиједака тај степен индивидуалности постаје препознатљив корак на путу стварања српске ауторске (и како се, донекле неадекватно каже - умјетничке) приповијетке (Иванић 2015: 11).

О приповедачком дару Вука Караџића сведоче још његови савременици и први биографи (Грим, Срезњевски, Платон Кулаковски и др.), а о изграђеном приповедном стилу, наративним поступцима и епском тону најистакнутији историчари и теоретичари књижевности, али и писци 20. века. Ипак, први је Миљан Мојашевић сагледао Вукове поступке стилизације српских народних приповедака као смишљен поетички поступак, заступајући став да се њихов стил и језик мора тумачити у склопу Вуковог индивидуалног приповедачког умећа. ${ }^{2}$

2 „О Вуковом усменом приповједачком дару свједоче различити извори (Ј. Грим, И. И. Срезњевски и др.). То се потврђује и у текстовима који су се тицали непосредног искуства, у предочавању динамике збивања и појединостима животне стварности (нарочито у преписци). О томе први научно проговара Платон Кулаковски поводом Вукових историјских списа („сјајан приповедачки дар”, „живост његовог приповедања”, „епски тон”) (Кулаковски 1987, 81). Послије чланка Слободана Јовановића (Гласник Професорског друштва, 1938: 34), то постаје опште мјесто у изучавању претежно оне Вукове прозе која је неспорно 
У којој мери се Андрић користи вуковском филолошком нормом и језиком народне традиције? Спором и разливеном реченицом, са бројним рукавцима у којима се љеска лексичка густина материјалних појмова фолклорне реченице? Фразеологизмима? Кратким говорним облицима? Предањима? Микрожанровима?

Код Андрића све тече споро и разливено, без везивног ткива дијалога, без метафоричких сонди, са мноштвом преопширних описа; одједном, тако се монотоно згусне, заигра живи, опори материјал визије; сувом дескрипцијом која подсећа на неку хронику, изведу се токови једне очигледне реалности која смишљено и магично организује лик, сцену и живот на њој (Џаџић 1957: 143).

У Андрићевом „ауторском гласу”, како је то луцидно запазила Исидора Секулић, ${ }^{3}$ сусрећу се мудрац Истока и префињени лирик Запада, тумач најстаријих легенди човечанства (в. Сувајџић 2012). Попут Вука, и Андрић задире у суштину поетике културно-историјског предања, у све његове области и видове, он открива и њихову функцију и сам постајући „визионар виших веза” између историје и традиције (Милошевић-Ђорђевић 2002: 20).

Приповетка „Пут Алије Ђерзелеза” (1920) означила је „Андрићев прелазак од лирско-прозног облика, тј. трансформацију субјективног начина транспоновања појава, преломљених у личној свести, у објективисане приповедачке визије" (Вучковић 2011: 160). Андрићев Ђерзелез евоцира епски предложак, али га и укида. ${ }^{4}$ Говорећи о „Путу Алије Ђерзелеза”, Св. Кољевић наглашава да је то „књижевност која настаје на историјској, митској или легендарној подлози, али за разлику од историјског

израз његовог пуног ауторства (историографски, биографски, етнографски списи, писма). О томе су писали Андрић, потом Драгиша Живковић, Миливој Павловић, Миодраг Поповић, Радован Самарџић и др. Међутим, кад је ријеч о издању Српских народних приповиједака, одлучујући рез је направио Миљан Мојашевић, студијом „О Вуковој стилизацији српских народних приповиједака” (1953) (Немачко-југословенске књижевне везе, 1974. године) (Иванић 2015: 6).

3 „Прво од источних обележја Андрићеве приче лежи у начину излагања садржине, који подсећа на усмено причање” (Секулић 1962: 61).

4 „Тамо где су наши усмени песници стали, тамо где су завршили повест великог муслиманског јунака, Андрић је управо почео. Јер онај Алија Ђерзелез који је 'несрећан, славан и смијешан', за кога је 'пут до жене тако вијугав и тајан', који, 'у силној и смијешној страсти, цио свој вијек пружа руке као у сну', тај трагичан јунак није Алија Ђерзелез народне књижевности. То је Андрићев Ђерзелез" (Недић 1976: 212). 
романа у 19. веку, она не приказује прошлост у романтичном светлу, него у слободном испитивању неких њених представа о животу тражи суштину човекове животне и моралне драме у историји" (Кољевић 1983: 33).

Андрићева „приповедачка визија митске прошлости”, изведена из „јасних и једноставних облика предања” (Џаџић 1957: 143), заснована је на врло широком регистру усмених фолклорних облика, од епске и лирске песме, предања, легенде, шаљиве приче, до краћих говорних умотворина, какве су загонетке, питалице, пословице, изреке, бајалице, клетве и заклетве, благослови и здравице (в. Сувајџић 2012).

Непрестана потреба за образлагањем хеременеутике народног стварања у Андрићевим наративним остварењима последица је пишчеве иманентне тежње за приближавањем усменом облику и изразу, као прототипу једноставног и прецизног реалистичког исказа. Утолико је Андрићево осветљавање Вука као писца од великог значаја за разумевање технике приповедања Иве Андрића, као и његовог синкретичног, на полугама историјског и митског искуства заснованог виђења света и живота.

И поред припадности различитим поетичким системима, са компаративног становишта, открива се несумњива духовна присност између Андрића и Вука, исказана у Андрићевим есејима, али и имплицитно, у њиховом стилу и језику. У врло сложеним наративним поступцима, у склопу реалистичке приповедне матрице, код Иве Андрића осећа се један ток приповедања који води до Вука и усмене народне приповетке, до матрице народне књижевности и поетике усменог обликовања. Андрић, наравно, на овом темељу остварује врхунски и аутентични приповедни стил и непоновљиви стваралачки израз.

\section{Литература}

Андрић 1977: Иво Андрић, „О Вуку као писцу”, у: Иво Андрић о Вуку, Избор, предговор и белешка о књизи Голуб Добрашиновић, Београд: Издавачко предузеће „Рад”.

Бован 1981: Владимир Бован, „Народне умотворине у Андрићевом делу”, у: Дело Иве Андрића у контексту европске књижевности и културе, Београд: Задужбина Иве Андрића.

Вучковић 2011: Радован Вучковић, Велика синтеза о Иви Андрићу, Београд: Алтера; Ниш: Филозофски факултет. 
Добрашиновић 1977: Голуб Добрашиновић, „Иво Андрић и Вук”, у: Иво Андрић о Вуку, Избор, предговор и белешка о књизи Голуб Добрашиновић, Београд: Издавачко предузеће „Рад”.

Еко 2015: Umberto Eko, „O nekim funkcijama književnosti”, u: $O$ književnosti, prevela Milana Piletić, Beograd: Vulkan izdavaštvo.

Живковић 1965: Драгиша Живковић, Од Вука до Андрића, Београд: Друштво за српскохрватски језик и књижевност СР Србије.

Иванић 2014: Вук Стефановић Караџић, Срби сви и свуда: о кюижевности и језику (предговори, критике, полемике, члании, писма), приредио Душан Иванић, Андрићград: Андрићев институт.

Иванић 2015: Душан Иванић. „Ауторски глас у српским народним приповијеткама Вука Караџића", Научни састанак слависта у Вукове дане, 44/2, Београд: Међународни славистички центар.

Јовановић 1991: Слободан Јовановић, „Вук као сликар историских личности (1937/38)", у: Слободан Јовановић, Из историје и књижевности I, приредио Живорад Стојковић, Сабрана дела Слободана Јовановића, том 11, Београд: БИГЗ, Југославијапублик, СК3, 659-665.

Кољевић 1983: Светозар Кољевић, Приповетке Иве Андрића. Београд: Завод за уџбенике и наставна средства.

Крњевић 1980: Hatidža Krnjević, „Ivo Andrić o Vuku Karadžiću”, u: Živi palimpsesti ili o usmenoj poeziji, Beograd: Nolit.

Лауер 1981: Рајнхард Лауер, „Карактеристичан стилски поступак у прози Иве Андрића", Дело Иве Андрића у контексту европске књижевности и културе, Зборник радова са међународног научног скупа одржаног у Београду од 26. до 28. маја 1980, Београд: Задужбина Иве Андрића у Београду, 121-129.

Леовац 1979: Славко Леовац, Приповедач Иво Андрић, Нови Сад: Матица српска.

Матицки 2017: Миодраг Матицки, „Вукове народне приповетке - источник аутентичне српске прозе са средине 19. века”, у: Вук Караџић, Сриске народне приповијетке, Предговор и приређивање Миодраг Матицки, Београд: Лагуна и Вукова задужбина, 13-37.

Милошевић 1963: Нада Милошевић, „Обрада фолклора у делима Иве Андрића", Рад IX конгреса фолклориста Југоставије, Сарајево.

Милошевић Ђорђевић 2002: Н. Милошевић Ђорђевић, Казивати редом. Прилози проучавағу поетике усменог ствараға, Библиотека „Вуков сабор", Београд: Рад-КПЗ Србије. 
Недић 1976: Владан Недић, „Иво Андрић и народна књижевност”, у: O yсменом песништву, прир. Мирослав Пантић, Београд: СКЗ, коло LXIX, Књ. 462.

Николић 2012: Ненад Николић, „Иво Андрић о Вуку Караџићу”, у: Иво Андрић у српској и европској кюижевности, Научни састанак слависта у Вукове дане, 41/2, Београд: Међународни славистички центар, 367-385.

Палавестра 1981: Predrag Palavestra, Skriveni pesnik. Prilog kritičkoj biografiji Ive Andrića, Beograd: Slovo ljubve.

Пантић 1984: Мирослав Пантић, Сусрети с прошлошћу, Београд: Просвета.

Радуловић 2015: Немања Радуловић, „Вук и Механџић: Проблем схватања народне приповетке”, у: Вук Стефановић Караиић (1787 - 1864 2014), ур. Н. Милошевић Ђорђевић, Београд: САНУ, 385-395.

Сабрана дела Иве Андрића. Београд: Просвета, БИГЗ-СКЗ-НОЛИТ, 1991.

Секулић 1962: Исидора Секулић, „Исток у приповеткама Ива Андрића”, у: Критичари о Андрићу, Београд.

Селимовић 1983: Meša Selimović, Za i protiv Vuka, Sabrana dela u 10 knjiga, 5, Beograd: BIGZ.

Сувајџић 2012: Бошко Сувајџић, Дновиде воде (Фолклорни елементи у српској къижевности), Нови Сад: Orpheus - Београд: Филолошки факултет.

Сувајџић 2015: Бошко Сувајџић, „Вукова Пјеснарица као отворено дело”, Савремена српска фолклористика 2, Београд: УФС, ИКУМ, УБ Светозар Марковић, 125-147.

Тартаља 1979: Иво Тартаља, Приповедачева естетика: прилог познавағу Андрићеве поетике, Београд: Нолит.

Џаџић 1957: Петар Џаџић, Иво Андрић. Есеј, Београд: Просвета

Џаџић 1991: Џаџић, Петар, „Иво Андрић: легенда, прича, мит историја”, у: На Дрини ћуприја, Сабрана дела Иве Андрића, књ. I, Београд. 
Boško Suvajdžić

IVO ANDRIĆ ABOUT VUK AS A WRITER

\section{Summary}

As it is well known,Andrić devoted nine of his studies, essays, occasional reviews and articles to Vuk Karadžić. Despite the affiliation with different poetic systems, from a comparative point of view, it is discovered an undeniable spiritual closeness between Andrić and Vuk, revealed in Andrić's essays, but also, implicitly, in their style and language. 